\title{
Release of two-cell block by reduction of protein disulfide with thioredoxin from Escherichia coli in mice
}

\author{
S. Natsuyama, Y. Noda, K. Narimoto, Y. Umaoka and T. Mori \\ Department of Gynaecology and Obstetrics, Faculty of Medicine, Kyoto University, Kyoto 606, \\ Japan
}

\begin{abstract}
Summary. The development of mouse pronuclear-stage embryos in media containing various concentrations of thioredoxin was monitored and the influence of antithioredoxin immunoglobulin $\mathrm{G}$ (IgG) and heat-treated thioredoxin on the thioredoxininduced effects was evaluated. A significant increase in the number of four-cell embryos $(76 \cdot 3 \%)$ and blastocysts $(37 \cdot 3 \%)$ was observed when embryos were cultured in the medium containing $50 \mu \mathrm{g}$ thioredoxin $\mathrm{ml}^{-1}$ compared with the rates $(55 \cdot 8$ and $3.8 \%$, respectively) in the basic medium. The number of blastocysts increased significantly to a maximum of $70 \cdot 2 \%$ at $500 \mu \mathrm{g} \mathrm{ml}^{-1}$. The biological activity of thioredoxin was evident after dialysis, but was markedly impaired by the addition of anti-thioredoxin IgG to the culture medium. Treatment at $60^{\circ} \mathrm{C}$ for $5 \mathrm{~min}$ did not affect the enzymatic and biological activity of thioredoxin. More severe heat treatment $\left(121^{\circ} \mathrm{C}\right.$ for $\left.30 \mathrm{~min}\right)$ attenuated the enzymatic activity to $40 \%$ of its initial value and reduced the biological activity (number of blastocysts, from $77 \cdot 8$ to $51 \cdot 6 \%$ ).

These results indicate that the effect of thioredoxin on the two-cell block is due to the thioredoxin molecule itself, and suggest that disulfide formation within or between proteins resulting from oxidative stress is one of the major causes of the two-cell block.
\end{abstract}

Keywords: thioredoxin; embryo; mouse

\section{Introduction}

Mammalian preimplantation embryos exhibit retarded growth and developmental blockage in vitro (Wright \& Bondioli, 1981; Fisher, 1987). For example, in mice, embryos of outbred strains exhibit the developmental block at the two-cell stage in vitro (Whitten, 1957; Yanagimachi \& Chang, 1964; Whittingham, 1975). In humans, eggs fertilized in vitro show retarded growth at the four-cell and more advanced stages and few embryos grow to the blastocyst stage (Fishel, 1986). These phenomena are thought to be caused by deficiencies of the conventional culture system compared with the in vivo environment; neither growth retardation nor developmental blockage are observed in vivo.

Oxygen concentration in vitro (i.e. the atmosphere) is about 3-10 times higher than that in vivo (i.e. oviduct or uterus) (Bishop, 1956; Mastroianni \& Jones, 1965; Maas et al., 1976). Low oxygen tension of culture media has been reported to promote embryo development in many species (Whitten, 1970). We have shown that the two-cell block in mice is released by adding superoxide dismutase (SOD), a scavenger of superoxide anion radicals, to the culture medium (Noda et al., 1991). An additive effect of low oxygen and SOD on mouse embryo development has been demonstrated (Umaoka et al., 1992). Generation of reactive oxygen species in blocked embryos (Nasr-Esfahani et al., 1990a) and overcoming the two-cell block by apotransferrin and iron chelators, which suppress the Haber-Weiss reaction (Nasr-Esfahani et al., 1990b), have also been reported. Considering these results together, it is possible that the two-cell block in mice is due to damage to the embryos by oxygen radicals. 
It is known that oxygen radicals inactivate various enzymes and damage membranes and DNA (Halliwell \& Gutteridge, 1989). The sulfhydryl group of proteins, readily oxidized under oxidative stress (Brigelius, 1985), may be damaged by oxygen radicals resulting in blocked embryo development in vitro. Recently, thioredoxin (Laurent et al., 1964), a small heat-resistant enzyme (molecular mass of about $12 \mathrm{kDa}$ ), which promotes the redox reaction of sulfhydryl groups of proteins, was demonstrated to have a defensive role against oxidative stress (Holmgren, 1985). In this study the effects of thioredoxin on mouse embryo development were evaluated and the specificity of the enzyme was established by maintaining mouse embryo cultures in media containing thioredoxin, anti-thioredoxin IgG or heat-treated thioredoxin.

\section{Materials and Methods}

\section{Chemicals and enzymes}

Thioredoxin (from Escherichia coli) was purchased from Promega Co. (Madison, WI, USA). Before use, the thioredoxin preparation was dialysed extensively against distilled water followed by lyophilization. Pregnant mares serum gonadotrophin (PMSG) and human chorionic gonadotrophin (hCG) were purchased from Teikoku Zoki Co. (Tokyo, Japan). Bovine serum albumin (BSA), hyaluronidase (bovine) and insulin (bovine) were purchased from Sigma Chemical Co. (MO, USA). The other chemicals were of reagent grade and purchased from Nacalai Tesque Co. (Kyoto, Japan).

\section{Preparation of anti-thioredoxin antiserum and extraction of the IgG fraction}

The anti-thioredoxin antiserum was prepared by injecting the immunogen $\left(0.5 \mathrm{mg} \mathrm{ml}^{-1}\right)$, with Freund's complete adjuvant, into the dorsal skin of female rabbits six times at intervals of 2 weeks. The rabbits were bled 7 days after the last injection. The IgG fractions of anti-thioredoxin antiserum $(\alpha-\operatorname{Trx}-\operatorname{IgG})$ and normal rabbit serum (NRS-IgG) were recovered from a protein-A Sepharose 4B column (Duhamel et al., 1979). The IgG preparations were dialysed against distilled water and lyophilized.

Reactivity of $\alpha$-Trx-IgG was examined by the method of Ouchterlony \& Nilson (1978). Thioredoxin, BSA, human albumin, mouse liver homogenate and $\alpha$-Trx-IgG were added to the diffusion well and incubated at $4^{\circ} \mathrm{C}$ overnight. The formation of precipitation bands was examined.

\section{Heat treatment of thioredoxin}

Thioredoxin was dissolved in deionized water at $1 \mathrm{mg} \mathrm{ml}^{-1}$ and the solution was divided into three parts, which were then heat-treated (i) in a hot waterbath at $60^{\circ} \mathrm{C}$ for $5 \mathrm{~min}$, (ii) at $100^{\circ} \mathrm{C}$ for $30 \mathrm{~min}$, or (iii) in an autoclave at $121^{\circ} \mathrm{C}$ for $30 \mathrm{~min}$. The heat-treated thioredoxin specimens were freeze-dried and stored.

Enzyme activity of the heat-treated thioredoxin was assayed by a turbidimetric assay using dithiothreitol (DTT) and insulin (Holmgren, 1979). The heat-treated thioredoxin samples were dissolved in phosphate buffer $\left(0 \cdot 1 \mathrm{~mol}^{-1}\right)$ and then added to the reaction cuvette (volume $1.2 \mathrm{ml}$ ) at a final concentration of $60 \mu \mathrm{g} \mathrm{ml}^{-1}\left(5 \mu \mathrm{mol} \mathrm{l}^{-1}\right)$. Reaction media contained $0.13 \mathrm{mmol}$ insulin $\mathrm{l}^{-1}, 0.33 \mathrm{mmol}$ DTT $1^{-1}, 2$ mol EDTA $\mathrm{l}^{-1}$ and 0.1 mol phosphate buffer $1^{-1}$. Increase in absorbance at $650 \mathrm{~nm}\left(\mathrm{~A}_{650}\right)$ caused by splitting of insulin molecules was recorded using a Shimadzu UV-260 spectrophotometer. Thioredoxin activity was evaluated using the maximum increase in $A_{650}$ in one minute. Standard curves were made from original samples of thioredoxin at $0,2 \cdot 5,5,7 \cdot 5$ and $10 \mu \mathrm{mol}^{-1}$.

\section{Embryo collection and culture conditions}

TUCK (outbred) mice were purchased from A. Tuck and Son Ltd (Battlesbridge, UK). Female mice, aged 4-5 weeks, were injected i.p. with PMSG (5 iu) and hCG (5 iu) at an interval of $48 \mathrm{~h}$ to induce superovulation. They were then mated with 12-week-old male mice of the same strain. Vaginal plug formation was confirmed on the next morning (day 1 of pregnancy). Female mice were killed by cervical dislocation, and pronuclear-stage embryos were collected from the ampulla of oviducts by the scratching method $17 \mathrm{~h}$ after $\mathrm{hCG}$ injection. After the removal of cumulus cells with $0.1 \%$ hyaluronidase, all the embryos were pooled in an $80 \mu 1$ spot of Dulbecco's phosphate saline, and 10-18 embryos with normal morphology were placed into each experimental spot of medium at random and then cultured at $37^{\circ} \mathrm{C}$ under $5 \% \mathrm{CO}_{2}$ in air. Degenerated embryos were excluded.

The basic medium for embryo culture was Biggers-Whitten-Whittingham (BWW) solution (Biggers et al., 1971) supplemented with $0 \cdot 3 \%$ BSA. An $80 \mu 1$ spot of medium was placed in each well of the four-well multidish (Nunc Co., Denmark) and covered with mineral oil. Embryos were observed every $24 \mathrm{~h}$ under an Olympus IMT-2 microscope with a Nomarski differential interferometer. The culture efficacy in the following experiments was evaluated by determining the proportion of embryos reaching two-cell (day 2), four-cell (day 3) and blastocyst (day 5) stages. 


\section{Experiment 1: embryo culture in the thioredoxin-supplemented medium}

Pronuclear-stage embryos were cultured after adding various concentrations $\left(10,50,100,500\right.$ and $\left.1000 \mu \mathrm{g} \mathrm{ml}^{-1}\right)$ of thioredoxin to the basic medium. As a control, pronuclear embryos were cultured in the basic medium. Embryo cultures in cach thioredoxin-supplemented medium were started at the same time.

\section{Experiment 2: inhibition of thioredoxin-induced effects by $\alpha$-Trx-IgG}

Pronuclear-stage embryos were cultured in the following media: group 1, basic medium containing thioredoxin ( $\left.30 \mu \mathrm{g} \mathrm{ml} l^{-1}, 2 \cdot 5 \mu \mathrm{moll}^{-1}\right)$ : group 2, basic medium containing thioredoxin $\left(30 \mu \mathrm{g} \mathrm{ml}^{-1}\right)$ and NRS-IgG $\left(500 \mu \mathrm{g} \mathrm{ml} l^{-1}\right)$; group 3, basic medium containing thioredoxin $\left(30 \mu \mathrm{g} \mathrm{ml}^{-1}\right)$ and $\alpha$-Trx-IgG $\left(500 \mu \mathrm{g} \mathrm{ml}^{-1}\right)$; group 4, basic medium containing NRS-IgG $\left(500 \mu \mathrm{g} \mathrm{ml}^{-1}\right)$; group 5, basic medium containing $\alpha-\operatorname{Trx}-\operatorname{IgG}\left(500 \mu \mathrm{g} \mathrm{ml}^{-1}\right)$; and group 6, basic medium. Embryo cultures in the six groups were started at the same time.

\section{Experiment 3: influence of heat treatment on thioredoxin-induced effects}

Pronuclear-stage embryos were cultured after adding heat-treated thioredoxin at $500 \mu \mathrm{g} \mathrm{ml}^{-1}\left(41 \cdot 7 \mu \mathrm{mol} \mathrm{I}^{-1}\right)$ to the basic medium. As a control, pronuclear-stage embryos were cultured in the basic medium containing untreated thioredoxin $\left(500 \mu \mathrm{g} \mathrm{ml}^{-1}\right)$. Embryo cultures in each medium were started at the same time.

\section{Statistical analysis}

The results of each experiment were analysed by the $\chi^{2}$ test.

\section{Results}

Reactivity of $\alpha-\operatorname{Trx}-\lg G$ was examined by Ouchterlony`s method. A single precipitation band was observed between $\alpha$-Trx-IgG $(80 \mu \mathrm{g})$ and thioredoxin $(\mathrm{I} \mu \mathrm{g})$ (Fig. 1). No precipitation band was observed against BSA, human albumin and mouse liver homogenate at various amounts $(0 \cdot 1,1,10$ and $(00 \mu \mathrm{g})$.

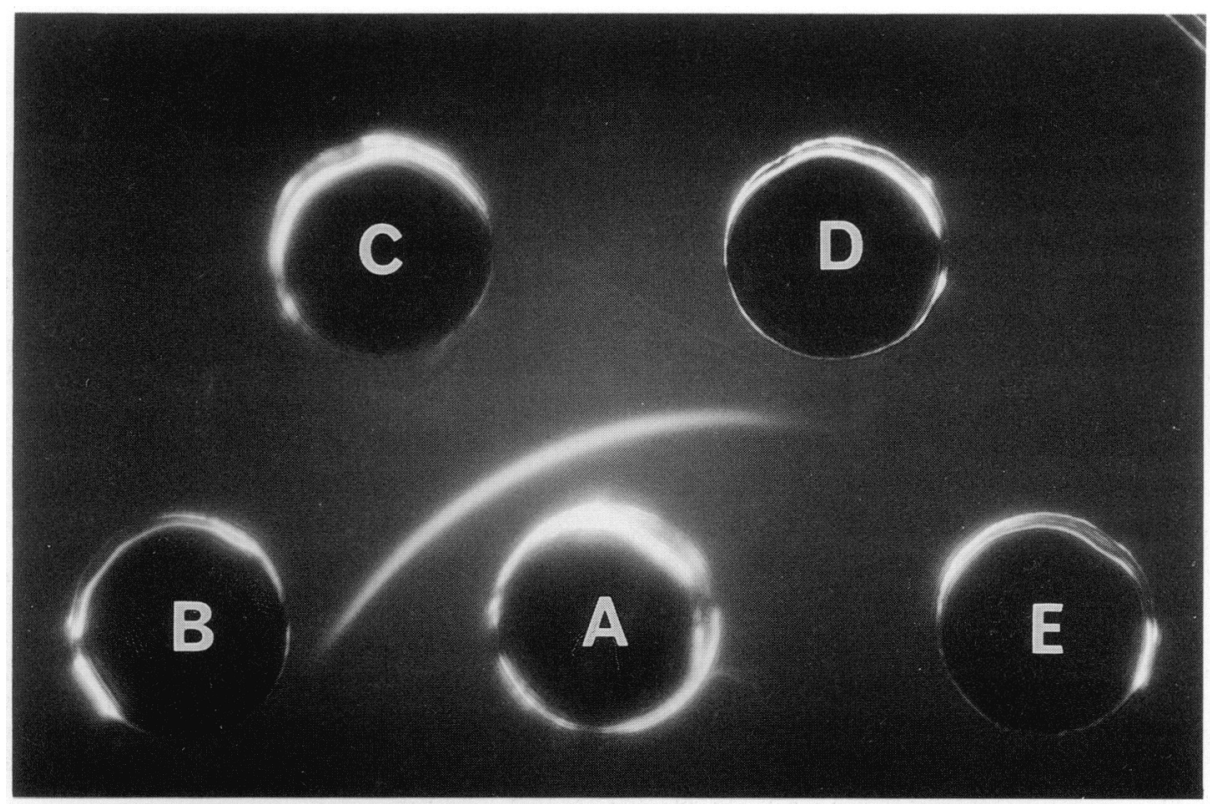

Fig. 1. Precipitation pattern between the immunoglobulin fraction of anti-thioredoxin rabbit antiserum $(\alpha-\operatorname{Trx}-\operatorname{IgG})$ and thioredoxin. A single precipitation band is observed between $\alpha-\operatorname{Tr} x-$ $\operatorname{IgG}(\mathrm{A}: 80 \mu \mathrm{g})$ and thioredoxin $(\mathrm{C}: 1 \mu \mathrm{g})$. No precipitation bands are found between $\alpha$-Trx-IgG $(80 \mu \mathrm{g})$ and BSA (B: $1 \mu \mathrm{g})$, human albumin $(\mathrm{D}: 1 \mu \mathrm{g})$, or mouse liver homogenate $(\mathrm{E}: 1 \mu \mathrm{g})$. 
The enzyme activity of heat-treated thioredoxin solution remained high after $5 \mathrm{~min}$ at $60^{\circ} \mathrm{C}$ (Table 1). Heat treatment at $100^{\circ} \mathrm{C}$ for $30 \mathrm{~min}$ and at $121^{\circ} \mathrm{C}$ for $30 \mathrm{~min}$ decreased enzymatic activity to $80 \%$ and $40 \%$ of that of untreated thioredoxin, respectively.

Table 1. Turbidimetric assay of thioredoxin

\begin{tabular}{lc}
\hline Specimens & $\begin{array}{c}\text { Enzymatic activity } \\
\left(\Delta \mathrm{A}_{650} \mathrm{~nm} \mathrm{m^{-1 }}\right)\end{array}$ \\
\hline Thioredoxin $\left(\mu \mathrm{mol} \mathrm{ml}^{-1}\right)$ & 0.000 \\
0 & 0.067 \\
2.5 & 0.093 \\
$5 \cdot 0$ & $0 \cdot 149$ \\
7.5 & 0.178 \\
$10 \cdot 0$ & 0.088 \\
Heat-treated thioredoxin $\left(5.0 \mu \mathrm{mol} \mathrm{ml}^{-1}\right)$ \\
$60^{\circ} \mathrm{C}, 5 \mathrm{~min}$ & 0.075 \\
$100^{\circ} \mathrm{C}, 30 \mathrm{~min}$ & 0.039 \\
$121^{\circ} \mathrm{C}, 30 \mathrm{~min}$ & \\
\hline
\end{tabular}

\section{Effects of thioredoxin on embryo development}

A significant increase in the numbers of embryos at the four-cell (day 3) (76.3\%) and blastocyst (day 5) $(37 \cdot 3 \%)$ stages was observed when the culture media contained $50 \mu \mathrm{g}$ thioredoxin $\mathrm{ml}^{-1}$ $\left(4.2 \mu \mathrm{mol}^{-1}\right)$, compared with culture in the basic medium $(55.8 \%, 3.8 \%)$. When the concentration was increased, the frequency of blastocysts also increased and then decreased gradually at higher concentrations (Table 2).

Table 2. Effects of thioredoxin on mouse embryo development

\begin{tabular}{|c|c|c|c|c|c|}
\hline \multirow[b]{2}{*}{ Conditions } & \multirow[b]{2}{*}{$\begin{array}{c}\text { Number of } \\
\text { trials }\end{array}$} & \multirow{2}{*}{$\begin{array}{l}\text { Number of } \\
\text { embryos } \\
\text { examined }^{\mathrm{a}}\end{array}$} & \multicolumn{3}{|c|}{ Number $(\%)^{b}$ of embryos developed to } \\
\hline & & & $\begin{array}{l}\text { two-cell } \\
\text { stage }\end{array}$ & $\begin{array}{l}\text { four-cell } \\
\text { stage }\end{array}$ & $\begin{array}{l}\text { blastocyst } \\
\text { stage }\end{array}$ \\
\hline \multicolumn{6}{|l|}{$\begin{array}{l}\text { Basic medium } \\
+ \text { thioredoxin } \\
\left(\mu \mathrm{g} \mathrm{ml}^{-1}\right)\end{array}$} \\
\hline 10 & 4 & 60 & $50(83 \cdot 3)$ & $31(51 \cdot 7)$ & $9(15 \cdot 0)$ \\
\hline 50 & 4 & 59 & $52(88 \cdot 1)$ & $45(76 \cdot 3)^{*}$ & $22(37 \cdot 3)^{* * *}$ \\
\hline 100 & 4 & 59 & $54(91 \cdot 5)$ & $44(74 \cdot 6)^{*}$ & $35(59 \cdot 3)^{* *}$ \\
\hline 500 & 4 & 57 & $49(86.0)$ & $48(84 \cdot 2)^{* *}$ & $40(70 \cdot 2)^{* *}$ \\
\hline 1000 & 4 & 55 & $46(83 \cdot 6)$ & $43(78 \cdot 2)^{*}$ & $34(61 \cdot 8)^{* *}$ \\
\hline 5000 & 4 & 57 & $52(91 \cdot 2)$ & $46(80 \cdot 7)^{* *}$ & $31(54.4)^{* *}$ \\
\hline $\begin{array}{l}\text { Basic medium } \\
\text { (control) }\end{array}$ & 4 & 52 & $46(88 \cdot 5)$ & $29(55 \cdot 8)$ & $2(3 \cdot 8)$ \\
\hline
\end{tabular}

${ }^{\text {a Pronuclear-stage embryos collected } 17 \mathrm{~h} \text { after administration of hCG. 12-16 embryos }}$ were used per experiment.

${ }^{b}$ Percentages of embryos at each stage represent cumulative totals.

${ }^{*} P<0.05 ;{ }^{* *} P<0.01$, compared with the control value.

\section{Inhibition of thioredoxin-induced effects by $a$-Trx-IgG}

Flocculate precipitates were observed $12 \mathrm{~h}$ after the addition of $\alpha$-Trx-IgG to the medium containing thioredoxin, but not otherwise. 
A significantly higher incidence of blastocysts was obtained by culture with thioredoxin alone $\left(28.1 \%\right.$, group 1) or with thioredoxin and $500 \mu \mathrm{g} \mathrm{NRS}-\mathrm{IgG} \mathrm{ml} \mathrm{m}^{-1}(28 \cdot 8 \%$, group 2$)$, compared with that $(4 \cdot 1 \%)$ noted in the basic medium (group 6). However, the incidence of blastocysts in the medium containing thioredoxin and $\alpha$-Trx-IgG in group 3 was low $(10.7 \%)$ and comparable with that found in the basic medium. The addition of NRS-IgG or $\alpha-\operatorname{Trx}-\operatorname{IgG}$ alone to the basic medium did not significantly affect the incidence of blastocysts (groups 4 or 5) (Table 3).

Table 3. Inhibition of thioredoxin-induced effects by $\alpha$-thioredoxin-IgG in mice

\begin{tabular}{|c|c|c|c|c|c|}
\hline \multirow[b]{2}{*}{ Conditions } & \multirow[b]{2}{*}{$\begin{array}{l}\text { Number of } \\
\text { trials }\end{array}$} & \multirow{2}{*}{$\begin{array}{l}\text { Number of } \\
\text { embryos } \\
\text { examined }\end{array}$} & \multicolumn{3}{|c|}{ Number $(\%)^{\mathrm{b}}$ of embryos developed to } \\
\hline & & & $\begin{array}{l}\text { two-cell } \\
\text { stage }\end{array}$ & $\begin{array}{l}\text { four-cell } \\
\text { stage }\end{array}$ & $\begin{array}{l}\text { blastocyst } \\
\text { stage }\end{array}$ \\
\hline$B W W+\operatorname{Trx}$ & 4 & 57 & $51(89 \cdot 5)$ & $40(70 \cdot 2)^{*}$ & $16(28 \cdot 1)^{* *}$ \\
\hline $\begin{array}{l}\text { BWW + Trx } \\
+ \text { NRS-IgG }\end{array}$ & 4 & 56 & $51(98 \cdot 1)$ & $27(51 \cdot 9)$ & $15(28 \cdot 8)^{* *}$ \\
\hline $\begin{array}{l}\text { BWW }+ \text { Trx } \\
+\alpha-\operatorname{Tr} x-\operatorname{IgG}\end{array}$ & 4 & 52 & $53(94 \cdot 6)$ & $15(26 \cdot 8)$ & $6(10 \cdot 7)$ \\
\hline $\begin{array}{l}\text { BWW } \\
\quad+\text { NRS-IgG }\end{array}$ & 4 & 60 & $59(98 \cdot 3)$ & $22(36 \cdot 6)$ & $1 \quad(1 \cdot 7)$ \\
\hline $\begin{array}{l}\text { BWW } \\
\quad+\alpha-\text { Trx-IgG }\end{array}$ & 4 & 63 & $62(98 \cdot 4)$ & $23(36 \cdot 5)$ & $4(6 \cdot 3)$ \\
\hline BWW (control) & 4 & 49 & $45(9 ! \cdot 8)$ & $23(46.9)$ & $2(4 \cdot 1)$ \\
\hline
\end{tabular}

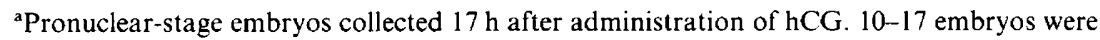
used per experiment.

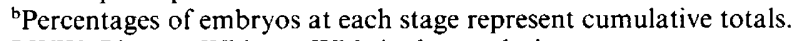

BWW: Biggers-Whitten-Whittingham solution.

Trx: Thioredoxin from Escherichia coli at $30 \mu \mathrm{g} \mathrm{ml}^{-1}$.

NRS-IgG: IgG fraction of normal rabbit serum at $500 \mu \mathrm{g} \mathrm{ml}^{-1}$

$\alpha$-Trx-IgG: IgG fraction of anti-thioredoxin antiserum at $500 \mu \mathrm{g} \mathrm{ml}^{-1}$.

${ }^{*} P<0.05 ; * * P<0.01$, compared with the control values.

\section{Influence of heat treatment on thioredoxin-induced effects}

A significant increase in the incidence of both the four-cell and blastocyst stages was observed in the culture media containing each heat-treated thioredoxin or untreated thioredoxin, compared with the incidence in the basic medium. The embryo promoting effect of thioredoxin was not influenced significantly by heat treatment at $60^{\circ} \mathrm{C}$ for $5 \mathrm{~min}$ or at $100^{\circ} \mathrm{C}$ for $30 \mathrm{~min}$, but was impaired by heat treatment at $121^{\circ} \mathrm{C}$ for $30 \mathrm{~min}$ (Table 4).

\section{Discussion}

In this study, we demonstrated that thioredoxin overcomes the two-cell block in mice and promotes the development of mouse embryos in vitro. The biological activity of thioredoxin was not lost after dialysis, but was markedly impaired after the addition of $\alpha$-Trx-IgG to the culture medium, indicating that the effect of the thioredoxin preparation on the two-cell block phenomenon is due to the thioredoxin molecule itself. Heat treatment at $60^{\circ} \mathrm{C}$ for $5 \mathrm{~min}$ did not diminish the enzymatic and biological activity of thioredoxin, showing the extraordinary heat stability of this enzyme (Laurent et al., 1964; Holmgren, 1985). Heat treatment at $121^{\circ} \mathrm{C}$ for 30 min reduced the enzymatic activity to $40 \%$ of initial values and decreased the biological activity even more, suggesting that the promotion of embryo development by thioredoxin is a phenomenon dependent on the enzyme activity of thioredoxin. 
Table 4. Influence of the heat treatment on thioredoxin-induced effects in mice

\begin{tabular}{|c|c|c|c|c|c|}
\hline \multirow[b]{2}{*}{ Conditions } & \multirow[b]{2}{*}{$\begin{array}{c}\text { Number of } \\
\text { trials }\end{array}$} & \multirow{2}{*}{$\begin{array}{l}\text { Number of } \\
\text { embryos } \\
\text { examined }^{a}\end{array}$} & \multicolumn{3}{|c|}{ Number $(\%)^{b}$ of embryos developed to } \\
\hline & & & $\begin{array}{l}\text { two-cell } \\
\text { stage }\end{array}$ & $\begin{array}{l}\text { four-cell } \\
\text { stage }\end{array}$ & $\begin{array}{l}\text { blastocyst } \\
\text { stage }\end{array}$ \\
\hline $\begin{array}{l}\text { BWW }+\operatorname{Trx} \\
\quad\left(60^{\circ} \mathrm{C}, 5 \mathrm{~min}\right)^{\mathrm{c}}\end{array}$ & 4 & 61 & $58(95 \cdot 1)$ & $53(86.9)$ & $45(73 \cdot 8)$ \\
\hline $\begin{array}{l}\mathrm{BWW}+\mathrm{Trx} \\
\left(100^{\circ} \mathrm{C}, 30 \mathrm{~min}\right)\end{array}$ & 4 & 64 & $60(93.8)$ & $51(79 \cdot 7)$ & $46(71 \cdot 9)$ \\
\hline $\begin{array}{l}\mathrm{BWW}+\mathrm{Trx} \\
\quad\left(121^{\circ} \mathrm{C}, 30 \mathrm{~min}\right)\end{array}$ & 4 & 64 & $61(95 \cdot 3)$ & $53(82 \cdot 8)$ & $33(51 \cdot 6)^{*}$ \\
\hline $\mathbf{B W W}+\operatorname{Trx}^{\mathbf{d}}$ & 4 & 63 & $59(93.7)$ & $55(87 \cdot 3)$ & $49(77 \cdot 8)$ \\
\hline BWW & 4 & 65 & $62(95.4)$ & $35(53 \cdot 8)$ & $3(4 \cdot 6)$ \\
\hline
\end{tabular}

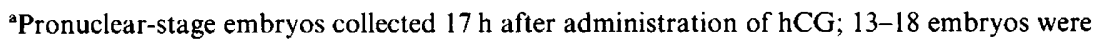
used per experiment.

bPercentages of embryos at each stage represent cumulative totals.

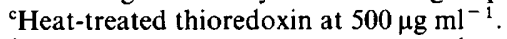

${ }^{d}$ Untreated thioredoxin at $500 \mu \mathrm{g} \mathrm{ml} \mathrm{I}^{-1}$.

${ }^{*} P<0.05$, compared with the control (BWW + Trx).

BWW: Biggers-Whitten-Whittingham solution; Trx: thioredoxin.

Many investigators have studied the in vitro two-cell block in mice since it was first reported by Whitten (1957). In an early study, a low oxygen concentration $\left(5 \% \mathrm{O}_{2}\right)$ was found to enhance the development of mouse embryos (Whitten, 1970). Recently, SOD, a scavenger of superoxide anion radicals, was shown to further enhance the effect of low oxygen concentrations on mouse embryo development (Noda et al., 1991) and an additive effect of low oxygen concentration and SOD on mouse embryo development was also described by Umaoka et al. (1992). It is therefore possible that the mouse two-cell block is primarily caused by damage to the embryo by reactive oxygen species generated in high oxygen tension media.

In general, with oxidative stress, the rates of disulfide bond formation and mixed disulfide formation increase within the cell (Brigelius, 1985; Park \& Thomas, 1989), resulting in the inactivation of enzymes, and reactive oxygen species are involved in protein disulfide formation (Halliwell \& Gutteridge, 1989). Thioredoxin is known to play a defensive role against oxidative stress by reducing protein disulfide bonds. For example, in higher plants, thioredoxin reactivates the oxidized enzymes involved in photosynthesis (Schurmann et al., 1981; Crawford et al., 1986; Jacquot \& Deottingnies 1986; Clancey \& Gilbert, 1987), and, in animals, ornithine decarboxylase is known to be repaired by thioredoxin (Flamigni et al., 1989). In mouse embryos, thioredoxin is also thought to promote development in vitro by facilitating the repair of oxidative changes of sulfhydryl groups.

Thioredoxin is a heat-stable small protein that is a hydrogen donor of Escherichia coli ribonucleotide diphosphate reductase and this protein is found in many prokaryotes and eukaryotes (Holmgren, 1985). The amino acid sequence of its active site is Cys-Gly-Pro-Cys and the two cysteine residues take part in a thiol-disulfide exchange reaction with a substrate (Holmgren, 1985). The thioredoxin that we added to the medium was an oxidized form, because only oxidized thioredoxin can be obtained from $E$. coli (Holmgren, 1985). As only the reduced form of thioredoxin is biochemically active and as culture media alone cannot reduce thioredoxin, the enzyme may be incorporated in the embryo where it is reduced by thioredoxin reductase using NADPH (Moore et al., 1964; Thelander, 1967). The incorporation of very small amounts of thioredoxin into lens cells has also been demonstrated (Spector et al., 1988).

The mechanism by which oxidative stress damages embryos remains to be established. The number of genomes of two-cell embryos blocked in vitro is $4 n$ (Goddard \& Pratt, 1983) and the embryos arrest after the S phase of the cell cycle (Luthardt \& Donahue, 1975; Goddard \& Pratt, 
1983), suggesting that a system that regulates the cell cycle from the $S$ to $M$ phase or a factor involved in cell division is damaged in the two-cell embryos blocked in vitro. The release of mouse two-cell block by thioredoxin suggests that the sulfhydryl group of proteins involved in cell division or cell cycle regulation is one of the targets of oxidative stress. For example, tubulin may be a target, because the sulfhydryl group in the cystine residue of tubulin, which is a component of the microtubules in the mitotic apparatus, is involved in the polymerization of tubulin to form the microtubules (Kuriyama \& Sakai, 1974).

In conclusion, we have demonstrated that thioredoxin releases mouse two-cell block and promotes the in vitro development of mouse embryos, and that the effects were induced by the thioredoxin molecule itself. Taking into consideration the fact that low oxygen concentration and SOD also promote development of embryos, we suggest that embryos must be carefully protected from oxidative stress in vitro. The precise mechanism of action of thioredoxin remains to be determined.

This study was supported by Grants in Aid for General Scientific Research B by the Ministry of Education, Science and Culture (No. 01480391) and for the Scientific Research on Priority Area (No. 0164004 and No. 02222104).

\section{References}

Biggers, J.D., Whitten, W.K. \& Whittingham, D.G. (1971) The culture of mouse embryos in vitro. In Methods in Mammalian Embryology, pp. 86-116. Ed. J. C. Daniel, Jr. Freeman Co., San Francisco.

Bishop, D.W. (1956) Oxygen concentration in the rabbit genital tract. In Proceedings of the Third International Congress of Animal Reproduction, Physiology. pp. 53-58. Ed. D.W. Bishop. Brown, Knight \& Truscott Ltd, Cambridge, UK.

Brigelius, R. (1985) Mixed disulfide. In Oxidative Stress, pp. 247 279. Ed. H. Sies. Academic Press, London.

Clancey, C.J. \& Gilbert, H.F. (1987) Thiol/disulfide exchange in the thioredoxin-catalized reductive activation of spinach chloroplast fructose-1,6-bisphosphatase. Kinetics and thermodynamics. Journal of Biological Chemistry 262, 13 545-13 549.

Crawford, N.A., Yee, B.C., Hutcheson, S.W., Wolosiuk, R.A. \& Buchanan, B.B. (1986) Enzyme regulation of $\mathrm{C} 4$ photosynthesis: purification, properties and activities of thioredoxin from $\mathrm{C} 4$ and $\mathrm{C} 3$ plants. Archives of Biochemistry and Biophysics 244, 1-15.

Duhamel, R.C., Schur, P.H., Brendel, K. \& Meezan, E. (1979) $\mathrm{pH}$ gradient elution of human IgG1, IgG2 and IgG4 from proteinA-sepharose. Journal of Immunology Methods 31, 211 217.

Fishel, S. (1986) Growth of the human conceptus in vitro. In In Vitro Fertilization, pp. 107-126. Eds S. Fishel \& E. M. Simonds. IRL Press, Oxford.

Fisher, B. (1987) Developmental retardation in cultured preimplantation rabbit embryos. Journal of Reproduction and Fertility. 79, 115123.

Flamigni, F., Marmiroli, S., Caldarera, C.M. \& Guarnieri, C. (1989) Involvement of thiol transferaseand thioredoxin-dependent systems in the protection of 'essential' thiol groups of ornithine decarboxylase. Biochemical Journal 259, $111-115$.

Goddard, M.J. \& Pratt, H.P.M. (1983) Control of events during early cleavage of the mouse embryo: an analysis of the 2-cell block. Journal of Embryology and Experimental Morphology 73, 111-133.
Halliwell, B. \& Gutteridge, J.M.C. (1989) Protection against oxidants in biological systems: the superoxide theory of oxygen toxicity. In Free Radicals in Biology and Medicine (2nd edn), pp. 86-187. Oxford University Press, New York.

Holmgren, A. (1979) Thioredoxin catalyses the reduction of insulin disulfides by dithiothreitol and dihydrolipoamide. Journal of Biological Chemistry. 254, 9627-9632.

Holmgren, A. (1985) Thioredoxin. Annual Review's of Biochemistry. 54, 237-271.

Jacquot, J.P. \& Decottingnies, P. (1986) Further evidence for a role of sulfhydryls in the thioredoxin dependent activation of corn NADP-malate dehydrogenase. Use of cysteine free mutant of $E$. coli thioredoxin. FEBS Letters 209, 87-91.

Kuriyama, R. \& Sakai, H. (1974) Role of tubulin-SH groups in polymerization to microtubules: functional-SH groups in tubulin for polymerization. Journal of Biochemistry 76, 651-654.

Laurent, T.C., Moore, E.C. \& Reichard, P. (1964) Enzymatic synthesis of deoxyribonucleotides: IV. isolation and characterization of thioredoxin, the hydrogen donor from Escherichia coli B. Journal of Biological Chemistry 239, 3436-3444.

Luthardt, F.W. \& Donahue, R.P. (1975) DNA synthesis in developing two-cell mouse embryo. Developmental Biology 44, 210-216.

Maas, D.H.A., Storey, B.T. \& Mastroianni, L., Jr (1976) Oxygen tension in the oviduct of the rhesus monkey (Macaca mulatta). Fertility and Sterility 27, 13121317.

Mastroianni, L., Jr \& Jones, R. (1965) Oxygen tension in the rabbit fallopian tube. Journal of Reproduction and Fertility 9, 99-102.

Moore, E.C., Reichard, P. \& Thelander, L. (1964) Enzymatic synthesis of deoxyribonucleotides: V. purification and properties of thioredoxin reductase from Escherichia coli B. Journal of Biological Chemistry 239, 3445-3452. 
Nasr-Esfahani, M.H., Aitken, J.R. \& Johnson, M.H. (1990a) Hydrogen peroxide levels in mouse oocytes and early cleavage stage embryos developed in vitro or in vivo. Development 109, 501-507.

Nasr-Esfahani, M.H., Johnson, M.H. \& Aitken, J.R. (1990b) The effect of iron and iron chelators on the in-vitro block to development of the mouse preimplantation embryo: BAT6 a new medium for improved culture of mouse embryos in vitro. Human Reproduction 5, 997-1003.

Noda, Y., Matsumoto, H., Umaoka, Y., Tatsumi, K., Kishi, J. \& Mori, T. (1991) Involvement of superoxide radicals in the mouse 2-cell block. Molecular Reproduction and Development 28, 356-360.

Ouchterlony, O. \& Nillson, L.A. (1978) Immunodiffusion and immunoelectrophoresis. In Handbook of Experimental Immunology, pp. 19.1-19.44. Ed. D. M. Weir. Blackwell Scientific Publications, London.

Park, E.M. \& Thomas, J.A. (1989) Reduction of protein mixed disulfides (dethiolation) by Escherichia coli thioredoxin: a study with glycogen phosphorylase $b$ and creatine kinase. Archives of Biochemistry and Biophysics 272, 25-31.

Schurmann, P., Maeda, K. \& Tsugita, A. (1981) Isomers in thioredoxins of spinach chloroplasts. European Journal of Biochemistry 116, 37-45.

Spector, A., Yan, G.Z., Huang, R.R.C., McDermott, M.J., Gascoyne, P.R.C. \& Pigiet, V. (1988) The effect of $\mathrm{H}_{2} \mathrm{O}_{2}$ upon thioredoxin-enriched lens epithelial cells. Journal of Biological Chemistry 263, 4984-4990.

Thelander, L. (1967) Thioredoxin reductase: characterization of a homogeneous preparation from Escherichia coli B. Journal of Biological Chemistry 242, 852-859.

Umaoka, Y., Noda, Y., Narimoto, K. \& Mori, T. (1992) Effects of oxygen toxicity on early development of mouse embryos. Molecular Reproduction and Development 31, 28. 33.

Whitten, W.K. (1957) Culture of tubal ova. Nature 179, 1081-1082.

Whitten, W.K. (1970) Nutrient requirements for the culture of preimplantation embryos in vitro. In Advances in the Biosciences 6, pp. 129-141. Ed. G. Raspe. Pergamon Press, Oxford.

Whittingham, D.G. (1975) Fertilization, early development and storage of mammalian ova in vitro. In The Early Development of Mammals, pp. 1-24. Eds M. Balls \& A. E. Wild. Cambridge University Press, Cambridge.

Wright, R.J., Jr \& Bondioli, K.R. (1981) Aspects of in vitro fertilization and embryo culture in domestic animals. Journal of Animal Science 53, 702-728.

Yanagimachi, R. \& Chang, M.C. (1964) In vitro fertilization of golden hamster ova. Journal of Experimental Zoology' 156, 361-376.

Received 22 April 1991 